\title{
Viral Hepatitis B: Clinical and Epidemiological Characteristics
}

\author{
Gregory S. Burns and Alexander J. Thompson \\ Department of Gastroenterology, St. Vincent's Hospital and The University of Melbourne, \\ Melbourne 3065, Australia \\ Correspondence: alexander.thompson@svha.org.au
}

It is now 50 years since the discovery of the hepatitis B virus (HBV), and, despite the availability of a prophylactic vaccine for more than 20 years, HBV infection remains a disease of significant global health burden. It is estimated that more than 240 million people are chronically infected with HBV and, therefore, are at risk for the development of cirrhosis, hepatic decompensation, and hepatocellular carcinoma (HCC). The risk of clinical complications has traditionally been higher in older males with hepatitis B e antigen ( $\mathrm{HBeAg}$ positive disease, high-grade liver necroinflammation, and progressive fibrosis. Recent advances in the understanding of the natural history of chronic HBV infection have identified an important role for plasma HBV DNA levels as a marker of risk for clinical outcomes. Among adults, persistent high-level HBV replication is associated with an increased risk of cirrhosis, as well as HCC development. This has led to the therapeutic focus on achieving sustained viral suppression. There is an emerging role for quantitative hepatitis B surface antigen ( $\mathrm{HBsAg}$ ) levels as a marker of natural history. Low levels of HBsAg have been associated with sustained immune control, $\mathrm{HBsAg}$ seroclearance, as well as lower risk of HCC. In this work, we review the natural history of HBV infection, with a focus on the determinants of clinical outcomes in patients with chronic hepatitis $\mathrm{B}(\mathrm{CHB})$ infection.

$\mathrm{O}$ utbreaks of jaundice have been documented since Hippocrates; however, the first description of an epidemic of "serum hepatitis" was by Lurman. In 1885, Lurman documented an epidemic of hepatitis among 191 German ship workers in Bremen after a smallpox vaccination campaign using human lymph (Lurman 1885). The largest documented outbreak of serum hepatitis occurred in 1942, when 50,000 U.S. Army personnel were hospitalized with jaundice following vaccination with contaminated lots of yellow fever vaccine in an epidemic affecting 300,000 American troops (Freeman 1946; Norman et al. 1993). Although clinicians recognized the syndromes of "infectious hepatitis" (hepatitis Avirus [HAV]) and "serum hepatitis" (HBV) at the time, the causative agents remained elusive. It was not until 1964 that Blumberg et al. (1965) serendipitously discovered a novel antigen in the sera of an Australian Aborigine, which precipitated antibodies in patients with acute leukemia who had received multiple blood transfusions. Termed the "Australia antigen," it was initially postulated as a

Editors: Christoph Seeger and Stephen Locarnini

Additional Perspectives on Hepatitis B and Delta Viruses available at www.perspectivesinmedicine.org

Copyright (C) 2014 Cold Spring Harbor Laboratory Press; all rights reserved; doi: 10.1101/cshperspect.a024935

Cite this article as Cold Spring Harb Perspect Med 2014;4:a024935 
biomarker to aid in the diagnosis of leukemia. It took another 3 years for the association between Australia antigen and posttransfusion hepatitis to be recognized, and the Australia antigen would become the prototypal seromarker of active hepatitis B, the HBsAg (Blumberg et al. 1965). Blumberg would go on to win the Nobel Prize in medicine for his work. Dane et al. (1970) later took HBsAg-positive sera and visualized the complete hepatitis B virion using electron microscopy.

It is now 50 years since the discovery of HBV and, yet, the diseases it causes (hepatitis, liver failure, and HCC) remain major public health challenges. In spite of the development of an effective vaccine and its implementation through the 1980s, there remains a huge global burden of liver disease caused by chronic hepatitis B (CHB). Worldwide, more than 240 million people have $\mathrm{CHB}$, with the majority being in the Asia-Pacific region, and there are at least one million deaths each year as a direct consequence of infection (Ott et al. 2012).

\section{EPIDEMIOLOGY OF HEPATITIS B}

\section{Acute Hepatitis B}

Symptomatic acute hepatitis B infection (AHB) remains, primarily, a disease of adulthood. The introduction of the HBV vaccine has had a dramatic impact on the reported incidence of AHB. In the United States, the reported rate of AHB has declined since 1990, decreasing from 8.5 per 100,000 population to 0.9 per 100,000 population in 2011 , the lowest rate ever recorded (Wasley et al. 2007; www.cdc.gov/ hepatitis/statistics/index.htm). In the same survey, the highest rates of AHB occurred among persons aged $30-39 \mathrm{yr}(2.0 / 100,000)$, and the lowest rates occurred among persons aged $<19$ yr $(0.04 / 100,000)$. The most common risk factors were sexual exposure (sexual contact with a person known to have HBV infection, multiple sex partners, and men having sex with men) and injecting drug use. Similar trends have been seen in other countries, including Italy and Egypt, where the frequency of acute HBV infection as a cause of symptomatic hepatitis decreased from $43.4 \%$ in 1983 to $28.5 \%$ in
2002, following the introduction of childhood immunization in 1991 (Zakaria et al. 2007).

\section{$\mathrm{CHB}$}

It is estimated that there are 240 million people who are chronically infected with HBV globally (Ocama et al. 2005). 15\%-40\% of infected patients will develop serious liver disease, resulting in up to 1.2 million deaths per year. HBV infection is the tenth leading cause of death worldwide (Lavanchy 2004).

Chronic HBV is endemic in Southeast Asia, China, sub-Saharan Africa, Micronesia and Polynesia, and the indigenous populations of Alaska, Northern Canada, Greenland, Australia, and New Zealand. In these high-prevalence regions, $>7 \%$ of the population is chronically infected (Maynard 1990). Patterns of infection vary considerably from country to country, city to city, and even village to village, and can change with time. Most infections are acquired early in childhood and the risk of chronicity is inversely related to the age of infection (Gust 1996). Approximately $45 \%$ of the global population lives in an area of high prevalence (Lavanchy 2004). Moderate prevalence rates of $2 \%-7 \%$ are seen in the southern regions of Eastern and Central Europe, the Amazon basin, the Middle East, and the Indian subcontinent (Mast et al. 1999). Low-prevalence regions include much of North America, the United Kingdom, and Northern Europe, where the incidence of chronic HBV infection is $<2 \%$. In these countries, $\mathrm{HBV}$ is seen predominantly in immigrants from countries with high prevalence and their unvaccinated offspring as well as in specific groups with percutaneous and sexual risk factors.

\section{TRANSMISSION}

HBV can be detected in serum, urine, saliva, nasopharyngeal secretions, urine, tears, vaginal secretions, menstrual blood, and semen (Lavanchy 2004). The virus can, therefore, be transmitted by perinatal, percutaneous, or sexual exposure, or via close person-to-person contact in the presence of open cuts and sores (a common transmission method in children). The 
most common method of transmission is perinatal infection (Stevens et al. 1975).

The mode of transmission of HBV infection varies geographically. In high-prevalence areas, such as Southeast Asia and China, perinatal and early childhood horizontal transmission is most common, resulting in high levels of chronicity (95\% perinatal, $30 \%$ before $5 \mathrm{yr}$ of age). Perinatal transmission is likely to occur at birth or in the neonatal period. Given the efficacy of neonatal vaccination in utero, infection is probably uncommon. The primary determinants of vertical transmission are HBeAg status and HBV DNA levels. The transmission rate in HBeAg-positive women is $90 \%$ without vaccination, compared with $32 \%$ for HBeAg-negative women (Stevens et al. 1985).

In low-prevalence areas, sexual and percutaneous spread (primarily injecting drug use) is also seen. In this setting, HBV infection typically manifests as adult-acquired acute hepatitis (see below). Progression to chronic hepatitis is rare in the immunocompetent adult, occurring in $<1 \%$ of individuals (Sherlock 1987). Patients already infected with HIV or who are immunosuppressed for other reasons are at increased risk of chronicity after AHB (Bodsworth et al. 1989).

\section{Uncommon Modes of Transmission}

Transfusion-related hepatitis B is now uncommon in countries in which blood is obtained from unpaid donors screened for HBsAg and anti-hepatitis B core total antibodies (anti$\mathrm{HBc}$ ), with an estimated risk in the United States of 1/63,000 (Schreiber et al. 1996). Rates can be lowered even further with the introduction of nucleic acid amplification testing (NAT). Nosocomial HBV transmission still occurs despite the availability of vaccination and postexposure prophylaxis, although HBV infection in health care workers (HCW) has declined dramatically in countries with HCW vaccination programs (Mahoney et al. 1997). The most common route is patient-to-patient or patient-toHCW via needlestick injuries (syringe, suture needles) or scalpel. Nurses, dialysis staff, surgeons, dentists, and their assistants are at highest risk. Incomplete vaccination of staff, failure
HBV: Clinical and Epidemiological Characteristics

to apply universal precautions, and incorrect needle-disposal techniques are the most prevalent reasons for transmission. Knowledge of a patient's infectious status does not prevent exposure. HBV DNA levels are the best marker of infectivity.

Transmission from any organ donation from HBsAg-positive donors is well recognized, and all donations are screened for HBsAg. AntiHBc-positive liver donors can also transmit infection. This is less common in renal and other transplants (Wachs et al. 1995).

\section{CLINICAL MANIFESTATIONS}

\section{Acute Hepatitis B}

The incubation period of AHB varies from 1 to 4 mo postinfection. Clinical presentation varies from asymptomatic infection in twothirds of patients to icteric hepatitis and, rarely, fulminant liver failure. A serum-sickness-like illness, characterized by fever, arthralgias, and rash, may occur in the prodromal period, followed by constitutional symptoms, anorexia, nausea, jaundice, and right upper quadrant discomfort. Clinical symptoms coincide with biochemical abnormalities. The biochemical diagnosis of acute hepatitis is characterized by elevations in the concentration of serum alanine aminotransferase (ALT) and bilirubin. ALT values in AHB are usually $>500 \mathrm{IU} / \mathrm{mL}$, with ALT being higher than aspartate aminotransferase (AST). Elevations in bilirubin are usually modest, $5-10 \mathrm{mg} / \mathrm{dl}$ (85-170 umol/l). The symptoms and jaundice generally disappear after 13 mo, although fatigue may persist for months in some patients, even after normalization of liver function tests.

The most serious complication of AHB is fulminant hepatic failure (FHF). This is unusu$\mathrm{al}$, occurring in $<0.5 \%$ of patients, and defined as the onset of hepatic encephalopathy within 8 wk of the development of jaundice. The risk of FHF may be higher in patients acutely infected with basal core promoter or precore variants, coinfected with other hepatitis viruses, or with underlying liver disease. The development of coagulopathy (marked by an international nor- 
malized ratio $[$ INR] $>1.6$ ) should raise concern about the risk of development of FHF, and warrants consultation with a liver transplant center as the prognosis is poor.

\section{Chronic Hepatitis B}

Most cases of $\mathrm{CHB}$ occur in endemic populations as the result of perinatal or early childhood horizontal transmission. The natural course of disease is determined by the interplay between virus replication and the host immune response, and may be divided into a number of phases: (1) the immune tolerance phase, (2) the immune clearance phase, (3) the immune control phase, and (4) the immune escape phase (Fig. 1).

The immune tolerance phase is characterized by high levels of viral replication, with serum HBV viral load up to $10^{12} \mathrm{IU} / \mathrm{mL}$ and detectable HBeAg, but no evidence of active liver disease, as manifested by lack of symptoms, normal serum ALT measurement, and benign histology on liver biopsy. The quasi-species is dominated by a single dominant variant and HBV-specific T-cell responses are weak or undetectable (Webster et al. 2004). The immune tolerance phase usually lasts $10-30 \mathrm{yr}$, during which there is a very low rate of spontaneous HBeAg clearance, reported at only $15 \%$ after 20 yr of infection (Lok et al. 1987).

Transition from the immune tolerance to the immune clearance phase typically occurs during the second and third decades of life. This transition is marked by increased HBV-specific T-cell immunity, decreasing HBV DNA titers, increased serum ALT, and necroinflammatory histological changes. This phase is known as $\mathrm{HBeAg}$-positive $\mathrm{CHB}$. Immune pressure drives an increase in viral quasi-species diversity. The immune clearance phase may last for years, during which time disease activity fluctuates and progressive liver damage accumulates. The most important factor influencing prognosis appears to be prolonged viral replication at levels $>2000 \mathrm{IU} / \mathrm{mL}$ (see below). In a small percentage of patients, severe ALT flares result in hepatic decompensation and, rarely, death from hepatic failure. $\mathrm{HBeAg}$ seroconversion is used as the serological marker of the end of the immune clearance phase and correlates with a significant drop in viral load, often to undetectable levels and histological arrest or improvement. HBV is not cleared from the liver, however, and the nuclear covalently closed circular DNA (cccDNA) reser-

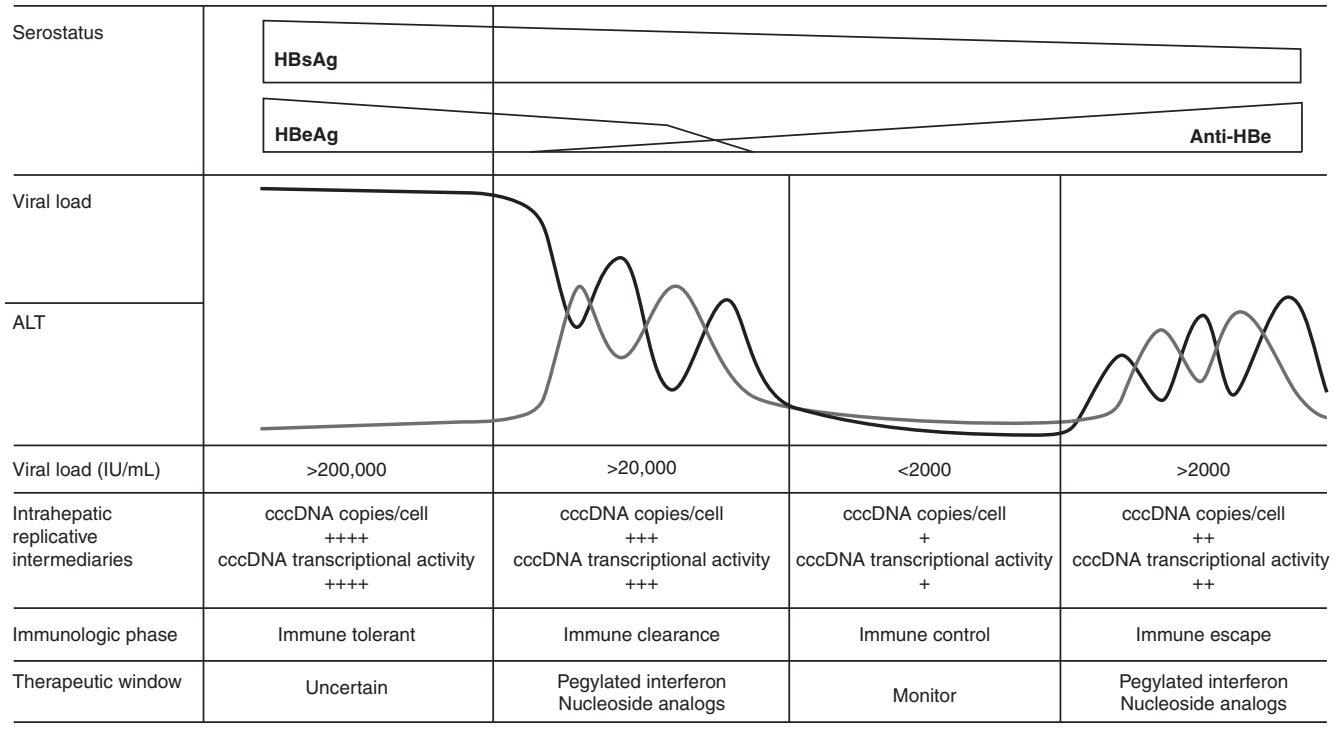

Figure 1. The natural history of $\mathrm{CHB}$, showing relationships between serology, biochemistry, and molecular virology. (Figure created from data in Lok and McMahon 2007.) 
voir persists. Spontaneous HBeAg clearance increases to an annual rate of $10 \%-20 \%$ during the immune clearance phase (Lok et al. 1987).

Patients in the immune control phase are HBeAg negative and anti-HBe positive. An arbitrary threshold, below which HBV replication is not thought to be clinically significant, has been set at $2000 \mathrm{IU} / \mathrm{mL}$ (Lok and McMahon 2007). In some patients, serum HBV DNA is no longer detectable, even when tested by sensitive polymerase chain reaction assays. Liver disease remits, as evidenced by normal serum ALT concentrations and resolution of necroinflammatory activity at histology. HBV-specific T-cell reactivity is high and thought to maintain viral suppression (Maini et al. 2000). The remaining HBV quasi-species is a diverse population, with a positive selection of viral variants defective for $\mathrm{HBeAg}$ production, that are able to persist, but at the cost of reduced replication phenotype (Lim et al. 2007; Volz et al. 2007). The annual rate of delayed clearance of HBsAg has been estimated to be $0.5 \%-2 \%$ in Western patients, but much lower $(0.1 \%-0.8 \%)$ in Asian populations (Alward et al. 1985; Liaw et al. 1991). HBsAg seroconversion is regarded as a "cure" and associated with a good prognosis. It is unlikely that HBV DNA is ever completely cleared from the liver, however, and a small risk of reactivation persists in the setting of potent immune suppression-like allogeneic bone marrow transplantation or HIV infection.

Some patients continue to have moderate levels of $\mathrm{HBV}$ replication and active liver disease (elevated serum ALT and histology showing chronic inflammation), but remain $\mathrm{HBeAg}$ negative. This usually occurs following the emergence of variants of HBV that are phenotypically $\mathrm{HBeAg}$ negative, genotypically include precore $(\mathrm{PC})$ or basal core promoter (BCP) mutants, and are known as HBeAg-negative CHBs. It remains unclear whether this occurs as a smooth transition from the $\mathrm{HBeAg}$-positive immune clearance phase or as reactivation from the immune control phase.

In adult-acquired $\mathrm{CHB}$, the immune tolerance phase is typically absent, with disease progressing immediately to the immune clearance phase. Some of these patients will be immuno-
HBV: Clinical and Epidemiological Characteristics

suppressed, and, in this setting, the disease course may be more aggressive. This has been clearly documented in the setting of HIV coinfection, which confers an increased risk of cirrhosis and liver-related morbidity (Thio et al. 2002). In immunocompetent adults, however, a higher rate of spontaneous and treatment-induced HBsAg seroconversion and lower rates of progression to cirrhosis occur.

\section{HBeAg-Positive $C H B$}

$\mathrm{HBeAg}$-positive $\mathrm{CHB}$ is associated with risk of liver fibrosis progression, cirrhosis, and HCC. A trial of observation for 3-6 mo to allow for spontaneous HBeAg seroconversion is reasonable for noncirrhotic patients, as spontaneous HBeAg seroconversion with sustained HBV DNA suppression is associated with improved long-term outcomes (EASL 2003; Liaw et al. 2005; Lok and McMahon 2007). However, a trial of therapy should then be offered to all patients with active disease, defined by a viral load $>20,000 \mathrm{IU} / \mathrm{mL}$, and either raised ALT $>2 \times$ the upper limit of normal (ULN) or moderate to severe inflammation on liver biopsy. In patients with an ALT $<2$ ULN in the presence of viral replication, the decision whether to commence therapy is influenced by the severity of both inflammation and fibrosis on the liver biopsy. The options for therapy include interferon-based therapy or one of the approved nucleoside analogs (NAs), which is discussed in detail in Zoulim and Durantel (2014).

\section{HBeAg-Negative $C H B$}

Patients in the immune escape phase are described as having HBeAg-negative CHB. Treatment is indicated to prevent the risk of progression to cirrhosis and HCC, and most guidelines recommend therapy for individuals with an HBV DNA level $>2000 \mathrm{IU} / \mathrm{mL}$ and evidence of moderate to severe inflammation or significant fibrosis (Lok and McMahon 2007). There is no agreed end point of therapy for patients with $\mathrm{HBeAg}$-negative CHB. Sustained virologic response may be achieved in a small percentage of patients using interferon-based therapy; 
however, most patients require prolonged therapy with an NA. Treatment decisions must weigh the risk of future clinical complications against the long-term costs and risk of antiviral resistance. Liver biopsy is useful in decision making as the presence of significant fibrosis should trigger consideration of therapy. In patients with mild fibrosis and inflammation, but ongoing replication, there are no data to determine whether the risk of long-term antiviral resistance outweighs the benefit of initial viral suppression, although the long-term risk of resistance among naïve patients treated with entecavir or tenofovir is very low. Treatment of HBeAg-negative CHB is discussed in detail in Zoulim and Durantel (2014).

\section{Sequelae of $\mathrm{CHB}$}

The major complications of $\mathrm{CHB}$ are cirrhosis, hepatic decompensation, and HCC. Extrahepatic manifestations can also occur. Between $15 \%$ and $40 \%$ of individuals with CHB will develop liver sequelae during their lifetime, with the highest risk in men (Beasley et al. 1982; Beasley 1988). CHB has a variable natural history and accurately predicting prognosis in an individual patient is difficult. Studies to identify the characteristics of patients at risk have been limited by the long duration of follow-up required. A key role has been identified for a serum HBV DNA level $>2000 \mathrm{IU} / \mathrm{mL}$ as a risk factor for clinical progression to cirrhosis and HCC (Chen et al. 2006a; Iloeje et al. 2006).

\section{Cirrhosis}

The current challenge in CHB is to identify patients at risk for progressive liver disease so that therapy may be offered early to alter the natural history. The major risk factors for progression to cirrhosis are viral load, the presence of fibrosis on liver biopsy, and elevated serum ALT. Other factors that influence progression to cirrhosis include viral genotype, quantitative surface antigen, coinfection with other viruses, such as hepatitis C virus (HCV), hepatitis D virus (HDV), and HIV, and alcohol consumption (Yim and Lok 2006).
In patients with $\mathrm{CHB}$, the strongest independent predictor of progression to cirrhosis is HBV viral load (Iloeje et al. 2006). In a prospective study of 3582 community-based HBsAgpositive Taiwanese aged $>30 \mathrm{yr}$, the risk of cirrhosis increased as baseline viral load increased (Iloeje et al. 2006), and a critical threshold of viral load of $2000 \mathrm{IU} / \mathrm{mL}$ was identified. The effect of viral load was independent of age, sex, cigarette smoking, alcohol consumption, $\mathrm{HBeAg}$ status, and alanine transaminase level. The annual incidence of cirrhosis was $0.9 \%$, lower than the reported rate of $2 \%-7 \%$ observed in tertiary referral center populations (Liaw et al. 1988; Fattovich et al. 1991; Hsu et al. 2002). A second large prospective study conducted in mainland China (Chen et al. 2006b) has confirmed this central role for viral load in prognostication (Iloeje et al. 2006). Whether these data can be extrapolated to younger patients, particularly those still in the immunotolerant phase of disease, or to HBsAg carriers in Western countries with adult-acquired HBV infection, remains unclear.

Elevated serum ALT, especially frequent ALT flares, have been shown to be risk factors for progressive disease (Hadziyannis and Papatheodoridis 2006). Mild elevations of serum ALT also predict for poor outcome, however, and it is likely that only a persistently low-normal serum ALT $(<0.5 \mathrm{ULN})$ is reassuring (Yuen et al. 2005). Liver biopsy remains a useful clinical tool, and histology has prognostic significance. The probability of evolution to cirrhosis is increased in patients with moderate to severe inflammatory changes (Liaw et al. 1988; Fattovich et al. 1991) or advanced fibrosis (Park et al. 2007).

Viral factors have been shown to have an influence on the risk of disease progression. In Asian countries, where genotypes $\mathrm{B}$ and $\mathrm{C}$ predominate, more rapid and frequent progression to cirrhosis has been noted in patients with genotype C disease (Chu et al. 2002; Sumi et al. 2003). Much of this risk is explained by the observation that the age of $\mathrm{HBeAg}$ seroconversion is greater in genotype $\mathrm{C}$ compared with genotype $\mathrm{B}$ patients, confirming the critical role of prolonged viremia. Genotype $\mathrm{C}$ disease has been associated with more advanced disease 
than genotype D in Western populations (Fattovich et al. 1988; Bell et al. 2005; Feld and Heathcote 2006). There are no natural history studies that compare all four of the major genotypes. In addition to genotype, a pathogenic role has been proposed for the common viral mutants associated with $\mathrm{HBeAg-negative} \mathrm{CHB}$. HBeAg-negative disease has been associated with severe and progressive disease; a significant proportion of patients have been found to have established cirrhosis on liver biopsy (Chu et al. 2003; Lin et al. 2005). The BCP mutation has been identified as a risk factor for cirrhosis (Fattovich et al. 1995). The role of the PC variant, the most common variant associated with HBeAg-negative disease, remains unclear.

\section{Hepatic Decompensation}

Decompensated liver disease develops as a complication of cirrhosis. The estimated 5-yr risk of progression to decompensation is $20 \%-23 \%$ (Realdi et al. 1994). Risk factors for decompensation and death include persistent viremia, age, and markers of impaired synthetic function (including low albumin, low platelets, high bilirubin, and ascites) (Liaw et al. 2004). Once decompensation occurs, the estimated 5-yr survival is $14 \%-35 \%$, compared with $80 \%-85 \%$ for compensated patients. The advent of NA therapy has had a dramatic impact on this natural history, again confirming the critical role viral replication plays in disease progression.

\section{HCC}

Seropositivity for HBsAg is one of the most important risk factors for the development of HCC. The relative risk of developing HCC associated with $\mathrm{HBsAg}$ positivity varies from sevenfold in Japan to 60- to 98-fold in Taiwan, likely proportional to the respective population attributable risks of $10 \%$ and $94 \%$, respectively (Chen et al. 2006a). More important for clinical practice is risk stratification for individual patients with $\mathrm{CHB}$.

Serum HBV DNA level has a profound impact on the risk of development of HCC in $\mathrm{CHB}$ patients (Chen et al. 2006a). A biological gradient of risk, according to a single measure-
HBV: Clinical and Epidemiological Characteristics

ment of serum HBV DNA level, was first defined in a large prospective Taiwanese cohort (the REVEAL cohort). These patients were older $(>30 \mathrm{yr})$, male (62\%), and the majority (85\%) were $\mathrm{HBeAg}$ negative. The cumulative incidence of HCC over $13 \mathrm{yr}$ of follow-up varied from $1.3 \%$ to $14.9 \%$ for HBV DNA levels of $<60 \mathrm{IU} /$ $\mathrm{mL}$ and $>200,000 \mathrm{IU} / \mathrm{mL}$, respectively. Individuals were at highest risk if HBV DNA level was persistently $>20,000 \mathrm{IU} / \mathrm{mL}$. Conversely, a significant reduction in HCC risk was observed in those who had a high HBV DNA level at baseline, but in whom viral load was significantly reduced at follow-up (Chen et al. 2006a). HBV DNA levels remained independent predictors of HCC even after adjusting for known covariates including male gender, older age, cigarette smoking, alcohol consumption, HBeAg positivity, raised serum ALT level, and the presence of cirrhosis at baseline. The importance of HBV DNA level in hepatic carcinogenesis was further emphasized in a second study that found that nucleoside analog therapy for patients with advanced fibrosis or cirrhosis reduces the risk of HCC (Liaw et al. 2004). HBsAg level is predictive of HCC development in the specific cohort of HBeAg-negative patients with HBV DNA level $<2000 \mathrm{IU} / \mathrm{mL}$ (see below).

The ERADICATE-B study assessed HBsAg level and risk of HCC in 2688 Taiwanese HBsAg-positive patients followed over a mean period of $14.7 \mathrm{yr}$ (Tseng et al. 2012). The cohort was predominantly male $(61 \%)$, aged $>28 \mathrm{yr}$, and genotype B (81\%). Similar to the REVEAL study, the risk factors for HCC were older age, male gender, elevated ALT, elevated HBV DNA level, and HBeAg positivity. HBsAg level was identified as an independent risk factor for HCC among HBeAg-negative patients with an HBV DNA level $<2000 \mathrm{IU} / \mathrm{mL}$. In this group, an HBsAg level $>1000 \mathrm{IU} / \mathrm{mL}$ was associated with an adjusted hazards ratio (HR) of 13.7 (95\% confidence interval [CI]: 4.8-39.3) (Tseng et al. 2012).

Viral factors that are associated with the development of HCC have been identified. Genotype $\mathrm{C}$ is associated with increased risk compared with genotype B (Kao et al. 2000; Yu et al. 2005; Tseng et al. 2012) in Asian populations, 
likely secondary to the prolonged high-level viremia, which occurs with genotype $\mathrm{C}$ infection. BCP mutations have been linked to hepatic carcinogenesis (Kao and Chen 2003). BCP mutations are more common in genotype $\mathrm{C}$ disease; again, a common factor may be the degree and duration of viremia. More recently, genotype F disease has been associated with the development of HCC among Alaskan native people (Livingston et al. 2007). High rates of HCC have been observed in young individuals from sub-Saharan Africa, which has been linked to African genotype A1 HBV (Kramvis and Kew 2007).

A number of groups have recently used data from large natural history studies in Asia to develop clinical risk calculators for point-of-care used to estimate individual patient risk for HCC development over time (Yang et al. 2014). Although these calculators are useful for the doctor-patient interaction and may influence clinical decision making, prospective validation of their import for guiding the decision to start antiviral therapy is warranted.

\section{HBsAg Quantification and Long-Term Outcomes of $\mathrm{CHB}$}

Although HBsAg quantification has been available for $>20 \mathrm{yr}$, more recent development of relatively inexpensive and rapid automated assays has led to investigation of its role in clinical decision making. Current assays for measuring HBsAg levels capture all forms of HBsAg, including virion-associated HBsAg and subviral particles. HBsAg levels may reflect hepatocyte cccDNA level and/or cccDNA transcriptional activity, as well as integrated HBV sequence, and its clinical utility may relate to a semi-quantitative measure of overall liver "HBV load" (Martinot-Peignoux et al. 2013). Several studies of variation in HBsAg levels during the natural history of hepatitis B have shown that HBsAg is highest during the immunotolerant phase and declines through the immune clearance and control phases (Fig. 2) (Nguyen et al. 2010). In this context, HBsAg level has been evaluated as a biomarker for the natural history of disease with a specific focus on risk of disease progression, and appears to have utility for defining stopping rules for peginterferon treatment. In a cohort of $542 \mathrm{HBeAg}$-positive patients undergoing interferon-based treatment, a sustained response was achieved in 51\% versus $16 \%$ of patients with a 12 -wk HBsAg level of $<1500 \mathrm{IU} / \mathrm{mL}$ versus $>20,000 \mathrm{IU} / \mathrm{mL}$, respectively (Lau and Brunetto 2009). In the PARC trial of $107 \mathrm{HBeAg}$-negative patients treated with peginterferon alfa-2a, a stopping rule of week $12 \mathrm{HBV}$ DNA decline of $<2 \log$ copies $/ \mathrm{mL}$,

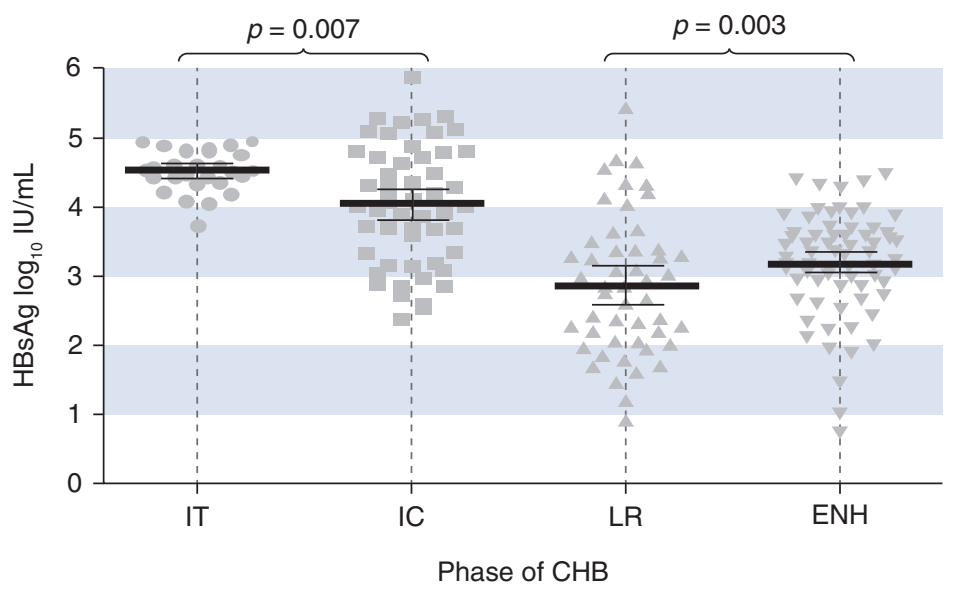

Figure 2. Distribution of serum HBsAg titres throughout the natural history of CHB. IT, immune tolerant; IC, immune clearance; LR, low replicative; ENH, HBeAg-negative hepatitis. (From Nguyen et al. 2010; reprinted, with permission, from Elsevier (C) 2010.) 
and no decline in HBsAg level identified a cohort of 20 patients whom would not achieve a sustained response (Rijckborst et al. 2010).

The level of HBsAg may differentiate the risk of immune escape among patients in the immune control phase of $\mathrm{CHB}$. Brunetto et al. (2010) investigated whether HBsAg quantification could predict persistence of the immunotolerant phase or progression to reactivation in a cohort of 209 genotype D patients with inactive hepatitis B. A combination of $\mathrm{HBsAg}$ $<1000 \mathrm{IU} / \mathrm{mL}$ and HBV DNA $<2000 \mathrm{IU} / \mathrm{mL}$ predicted maintenance of inactive carrier state at $3 \mathrm{yr}$ with an $87.9 \%$ positive predictive value. This has since been validated in a Taiwanese study of genotype B and C patients (Tseng et al. 2013).

Low HBsAg levels in the immune control phase of CHB have also been linked to the likelihood of HBsAg seroclearance. The ERADICATE-B study identified HBsAg levels to strongly predict for HBsAg loss over time (Chao et al. 1988). Among 688 HBeAg-negative patients with an HBV DNA $<2000 \mathrm{IU} / \mathrm{mL}$ at baseline, HBsAg clearance occurred at a rate of $1.6 \%$ per year. An HBsAg level of $<10 \mathrm{IU} / \mathrm{mL}$ was associated with an annual clearance rate of $7 \%, 13.2$ times that of patients with a baseline HBsAg >10,000 IU/mL. HBsAg levels were more useful for predicting long-term HBsAg seroclearance than HBV DNA levels.

Finally, HBsAg levels have been associated with risk of HCC development. Data from 3411 HBV carriers in the REVEAL study showed that both HBsAg and HBV DNA levels were independent predictors of HCC development. The multivariate-adjusted HR for HCC development increased from 1.0 (reference) for serum levels of HBV DNA/HBsAg of $<2000 /$ $<100 \mathrm{IU} / \mathrm{mL}$ to 9.22 (95\% CI: $4.34-19.58$ ) for serum levels of HBV DNA/HBsAg of $\geq 2000 / \geq 100 \mathrm{IU} / \mathrm{mL}$ (Lin and Kao 2013). Similar findings were observed in the ERADICATE-B study. Among 2688 noncirrhotic CHB individuals followed for a mean of $14.7 \mathrm{yr}$, the independent predictors of HCC risk were HBV DNA level (HR: 4.7; 95\% CI: 2.2-10.0), increased quantitative [q] HBsAg (HR: 7.2; 95\% CI: 1.8-28.6), and elevated ALT level (HR: 6.6;
HBV: Clinical and Epidemiological Characteristics

95\% CI: 2.2-19.8) (Tseng et al. 2012). HBsAg levels were most useful in patients with an $\mathrm{HBV}$ DNA level $<2000 \mathrm{IU} / \mathrm{mL}$; the risk of HCC for individuals with HBV DNA < 2000 IU/ $\mathrm{mL}$ and $\mathrm{HBsAg} \geq 1000 \mathrm{IU} / \mathrm{mL}$ was much higher than those with HBV DNA $<2000 \mathrm{IU} / \mathrm{mL}$ and HBsAg < $1000 \mathrm{IU} / \mathrm{mL}$ (HR: 13.7; 95\% CI: 4.8-39.3) (Tseng et al. 2012).

\section{HBsAg Seroclearance}

HBsAg seroclearance is the ultimate goal of treatment for individuals with $\mathrm{CHB}$. In the setting of long-term follow-up, some individuals with chronic HBV infection will eventually become HBsAg negative. Estimates of the annual rate of delayed clearance of HBsAg are much lower in Asian patients than among patients from the West $(0.1 \%-0.8 \%$ vs. $0.5 \%-2.0 \%)$ (Alward et al. 1985; Liaw et al. 1991; Liu et al. 2010). Among 3087 predominantly $\mathrm{HBeAg}$ negative patients enrolled in long-term followup in the REVEAL, HBsAg clearance occurred in 562 participants during 24,829 person-years of follow-up evaluation (an annual clearance rate of $2.26 \%$ ). Clearance was preceded by a decrease in HBV DNA. The cumulative incidence of HBsAg clearance after 5 and 8 yr was $\sim 26 \%$ and $51 \%$, respectively, in patients whose serum HBV DNA became undetectable. HBsAg clearance may be preceded by decreasing levels of HBsAg. As noted above, HBsAg levels of $<10 \mathrm{IU} / \mathrm{mL}$ were associated with an annual clearance rate of 7\% among individuals enrolled in the ERADICATE-B study, 13.2 times that of patients with a baseline $\mathrm{HBsAg}$ $>10,000 \mathrm{IU} / \mathrm{mL}$. HBsAg levels were more useful for predicting long-term HBsAg seroclearance than HBV DNA levels.

Patients who clear HBsAg appear to have a good prognosis (Chen et al. 2002). In a European study of 612 patients with compensated liver disease followed prospectively for $15 \mathrm{yr}$, 75 cleared HBsAg. Among those that cleared HBsAg, the incidence of liver-related complication (cirrhosis, hepatic decompensation, and HCC) was $1.8 \%$ compared with $11.6 \%$ for those with persistent HBsAg (Lauret et al. 2014). The benefit was greatest in patients with cirrho- 
sis. However, clearance of HBsAg does not completely remove the risk of HCC (Huo et al. 1998; Yuen et al. 2008). The age of seroclearance may be important, and seroclearance before the age of $50 \mathrm{yr}$ appears to be important. In a study from Hong Kong, the likelihood of developing HCC was greater in those who cleared HBsAg when older than age 50 (Yuen et al. 2008).

\section{Occult Hepatitis B}

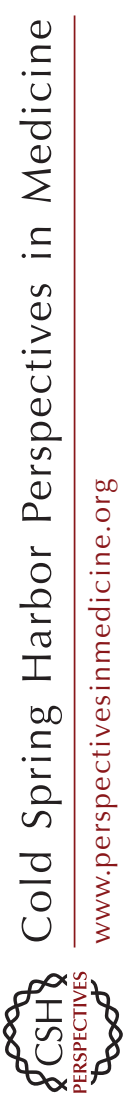

Occult HBV infection is defined by the presence of detectable HBV DNA in a patient in whom HBsAg is not measurable. In a small number of these patients, viral variants may be identified that produce an antigenically modified HBV S protein not detectable using commercial HBsAg assays, or carrying mutations that inhibit $\mathrm{S}$ gene expression (Raimondo et al. 2007). However, in most cases, the occult status does not seem to result from genomic heterogeneity. Rather, the occult expression results from strong suppression of viral gene expression. Most of these patients have very low-level HBV DNA in the serum (typically $10^{2}-10^{3} \mathrm{IU} /$ $\mathrm{mL}$ ), accounting for the failure to detect HBsAg. The epidemiology of occult HBV remains poorly defined. It remains rare in the Western world. It appears to be more common in endemic areas, in the setting of coinfection with HCV and HIV, in patients with a history of injecting drug use, hemophiliacs, and patients on hemodialysis (Raimondo et al. 2007). There is increasing evidence that occult $\mathrm{HBV}$ is relevant clinically. Occult HBV carriers may be a source of HBV transmission in the case of blood donation. There is a risk of viral reactivation in patients who are immunosuppressed. Although there is no prospective data, there is evidence to suggest an association between occult HBV and progressive liver fibrosis and HCC (Raimondo et al. 2007).

\section{Extrahepatic Manifestations}

HBV infection is associated with several extrahepatic manifestations, which are thought to be mediated by circulating immune complexes (Han 2004). These include the serum-sickness- like prodrome of acute HBV infection, polyarteritis nodosa (PAN), HBV-associated glomerulonephritis (GN), mixed essential cryoglobuliaemia, and neurological manifestations.

A serum-sickness-like prodrome precedes clinical hepatitis by $1-6 \mathrm{wk}$ in $10 \%-30 \%$ of those acquiring acute HBV infection. Also known as the "arthritis-dermatitis" syndrome, it is characterized by a symmetrical generalized inflammatory arthritis, typically involving the small joints of the hands and feet, which may be indistinguishable from acute rheumatoid arthritis. The joint lesions are nondestructive, however. Skin manifestations are variable, occurring in $>50 \%$ at the time of or shortly after the joint symptoms. Lesions described include maculopapular, petechial, or purpuric rash, palpable purpura, Henoch-Schönlein-type purpura, erythema multiforme, toxic erythema, lichenoid dermatitis, and urticaria. Fever is common. Renal involvement with proteinuria or hematuria is much less common. Angioneurotic edema may rarely occur.

PAN is a rare but serious complication of HBV infection. The syndrome normally presents within 4 mo of the clinical onset of HBV infection, with abdominal pain attributable to arteritis of medium-sized vessels causing ischemia of the intestine and gallbladder. The finding of microaneurysms of blood vessels in the renal, hepatic, or mesenteric circulations on angiography is virtually pathognomonic. Tissue biopsy of affected organs revealing inflammation of the medium-sized arteries confirms the diagnosis. Treatment involves antiviral therapy, immunosuppression, and plasma exchange. The prognosis is poor without treatment, with mortality of up to $50 \%$.

GN is more commonly associated with $\mathrm{CHB}$. The most common presentation is nephritic syndrome. A number of patterns of glomerular injury have been described, including membranoproliferative GN, membranous GN, and rarely mesangial proliferative GN. In children, the disease is usually self-limited; however, progression to renal failure has been described in adults. The association of HBV infection with mixed essential cryoglobulinemia is controversial. Rare cases have been reported; however, the 
majority of cases are now recognized to be associated with HCV infection (Ferri et al. 2004).

Other manifestations of HBV-related vasculitis include mononeuritis multiplex and polyneuropathy. Guillain-Barré syndrome has been reported. Associations with polymyalgia rheumatica, polymyositis, and HLA-B27-positive ankylosing spondylitis have also been reported, although a causative link remains controversial.

\section{HBV-HIV COINFECTION}

CHB affects $\sim 10 \%$ of HIV-infected patients. HIV impacts directly on the outcome of HBV infection, complicating its natural history, diagnosis, and management. In the setting of HIV/ HBV coinfection, levels of serum HBV DNA tend to be higher and spontaneous HBeAg seroconversion occurs at a lower rate. For reasons that remain unclear, liver damage, especially fibrosis, progresses at a faster rate than in HBV monoinfection, despite hepatic necroinflammation, typically being less severe. With improved control of HIV disease with highly active antiretroviral therapy (HAART), liver disease has emerged as one of the leading causes of death in patients with HIV (Thio et al. 2002).

Therefore, all patients with HIV should be screened for HBV infection. It is recommended that testing for both anti-HBc and HBsAg be performed, as patients with HIV can have occult HBV, with high levels of HBV DNA and anti$\mathrm{HBc}$, but not HBsAg. Similarly, all HBV patients should undergo HIV testing (Lok and McMahon 2007).

Anti-HBV therapy should be considered for all HIV/HBV-coinfected patients with evidence of liver disease, irrespective of the CD4 cell count (Thio and Locarnini 2007). In coinfected patients not requiring HAART, HBV therapy should be based on agents that do not target HIV. Entecavir, previously recommended as first-line therapy in this situation, is now recognized to have anti-HIV activity, and is associated with the accumulation of HIV-1 variants with the lamivudine-resistant mutation, M184V (McMahon et al. 2007). Therapeutic options, therefore, include ADV (10 mg) or PEG. Although LdT does not target HIV, its use as
HBV: Clinical and Epidemiological Characteristics

monotherapy is not recommended because of the risk of selection of the M204I mutation in the YMDD motif.

In contrast, in patients with $\mathrm{CD} 4$ counts $<350$ cells $/ \mu \mathrm{L}$, the use of agents with dual anti-HIV and -HBV activity should be considered. These include LMV (or FTC) and TDF, ideally as combination therapy. Rates of HBV resistance are more common in the setting of coinfection, and combination therapy will avoid or delay the development of antiviral resistance. Combination therapy may also limit the risk of immune reconstitution disease, resulting in serious hepatic flare and precipitating liver decompensation, a particular risk for patients presenting with advanced HIV infection and reduced functional hepatic reserve caused by HBV-related cirrhosis.

The hepatitis B vaccine should be given to all HIV-positive persons who are negative for $\mathrm{HBV}$ seromarkers. The vaccine should be given when CD4 cell counts are $\geq 200 / \mu \mathrm{L}$, as response is poor below this level. Persons with CD4 counts below 200 should receive HAART first, deferring the HBV vaccine until CD4 counts increase to $>200 / \mu \mathrm{L}$.

\section{REFERENCES}

${ }^{*}$ Reference is also in this collection.

Alward WL, McMahon BJ, Hall DB, Heyward WL, Francis DP, Bender TR. 1985. The long-term serological course of asymptomatic hepatitis B virus carriers and the development of primary hepatocellular carcinoma. J Infect Dis 151: 604-609.

Beasley RP. 1988. Hepatitis B virus. The major etiology of hepatocellular carcinoma. Cancer 61: 1942-1956.

Beasley RP, Lin CC, Chien CS, Chen CJ, Hwang LY. 1982. Geographic distribution of HBsAg carriers in China. Hepatology 2: 553-556.

Bell SJ, Lau A, Thompson A, Watson KJ, Demediuk B, Shaw G, Chen RY, Ayres A, Yuen L, Bartholomeusz A, et al. 2005. Chronic hepatitis B: Recommendations for therapy based on the natural history of disease in Australian patients. J Clin Virol 32: 122-127.

Blumberg BS, Alter HJ, Visnich S. 1965. A “new” antigen in leukemia sera. JAMA 191: 541-546.

Bodsworth N, Donovan B, Nightingale BN. 1989. The effect of concurrent human immunodeficiency virus infection on chronic hepatitis B: A study of 150 homosexual men. J Infect Dis 160: 577-582.

Brunetto MR, Oliveri F, Colombatto P, Moriconi F, Ciccorossi P, Coco B, Romagnoli V, Cherubini B, Moscato G, 
Maina AM, et al. 2010. Hepatitis B surface antigen serum levels help to distinguish active from inactive hepatitis B virus genotype D carriers. Gastroenterology 139: 483490.

Chao CF, Chen JY, Tseng YM, Ting LP. 1988. Cytochemical localization and biochemical analysis of the enzyme markers in human hepatoma cell lines. Proc Natl Sci Counc Repub China B 12: 222-227.

Chen YC, Sheen IS, Chu CM, Liaw YF. 2002. Prognosis following spontaneous HBsAg seroclearance in chronic hepatitis B patients with or without concurrent infection. Gastroenterology 123: 1084-1089.

Chen CJ, Yang HI, Su J, Jen CL, You SL, Lu SN, Huang GT, Iloeje UH. 2006a. Risk of hepatocellular carcinoma across a biological gradient of serum hepatitis B virus DNA level. JAMA 295: 65-73.

Chen G, Lin W, Shen F, Iloeje UH, London WT, Evans AA. 2006b. Past HBV viral load as predictor of mortality and morbidity from HCC and chronic liver disease in a prospective study. Am J Gastroenterol 101: 1797-1803.

Chu CJ, Hussain M, Lok AS. 2002. Hepatitis B virus genotype B is associated with earlier HBeAg seroconversion compared with hepatitis B virus genotype C. Gastroenterology 122: 1756-1762.

Chu CJ, Keeffe EB, Han SH, Perrillo RP, Min AD, SoldevilaPico C, Carey W, Brown RS Jr, Luketic VA, Terrault N, et al. 2003. Prevalence of HBV precore/core promoter variants in the United States. Hepatology 38: 619-628.

Dane DS, Cameron CH, Briggs M. 1970. Virus-like particles in serum of patients with Australia-antigen-associated hepatitis. Lancet 1: 695-698.

EASL. 2003. Proceedings of the European Association for the Study of the Liver (EASL) International Consensus Conference on Hepatitis B. Geneva, Switzerland, September 14-16, 2002. J Hepatol 39: S1-S235.

Fattovich G, Brollo L, Alberti A, Pontisso P, Giustina G Realdi G. 1988. Long-term follow-up of anti-HBe-positive chronic active hepatitis B. Hepatology 8: 1651-1654.

Fattovich G, Brollo L, Giustina G, Noventa F, Pontisso P, Alberti A, Realdi G, Ruol A. 1991. Natural history and prognostic factors for chronic hepatitis type B. Gut 32: 294-298.

Fattovich G, Giustina G, Schalm SW, Hadziyannis S, Sanchez-Tapias J, Almasio P, Christensen E, Krogsgaard K, Degos F, Carneiro de Moura M, et al. 1995. Occurrence of hepatocellular carcinoma and decompensation in Western European patients with cirrhosis type B. The EUROHEP Study Group on Hepatitis B Virus and Cirrhosis. Hepatology 21: 77-82.

Feld JJ, Heathcote EJ. 2006. Hepatitis B e antigen-positive chronic hepatitis B: Natural history and treatment. Semin Liver Dis 26: 116-129.

Ferri C, Sebastiani M, Giuggioli D, Cazzato M, Longombardo G, Antonelli A, Puccini R, Michelassi C, Zignego AL. 2004. Mixed cryoglobulinemia: Demographic, clinical, and serologic features and survival in 231 patients. Semin Arthritis Rheum 33: 355-374.

Freeman G. 1946. Epidemiology and incubation period of jaundice following yellow fever vaccination. Am J Trop Med Hyg 26: 15-32.
Gust ID. 1996. Epidemiology of hepatitis B infection in the Western Pacific and Southeast Asia. Gut 38: S18-S23.

Hadziyannis SJ, Papatheodoridis GV. 2006. Hepatitis B e antigen-negative chronic hepatitis B: Natural history and treatment. Semin Liver Dis 26: 130-141.

Han SH. 2004. Extrahepatic manifestations of chronic hepatitis B. Clin Liver Dis 8: 403-418.

Hsu YS, Chien RN, Yeh CT, Sheen IS, Chiou HY, Chu CM, Liaw YF. 2002. Long-term outcome after spontaneous HBeAg seroconversion in patients with chronic hepatitis B. Hepatology 35: 1522-1527.

Huo TI, Wu JC, Lee PC, Chau GY, Lui WY, Tsay SH, Ting LT, Chang FY, Lee SD. 1998. Sero-clearance of hepatitis B surface antigen in chronic carriers does not necessarily imply a good prognosis. Hepatology 28: 231-236.

Iloeje UH, Yang HI, Su J, Jen CL, You SL, Chen CJ. 2006. Risk evaluation of viral load E, associated liver disease/cancerin HBVSG: Predicting cirrhosis risk based on the level of circulating hepatitis B viral load. Gastroenterology 130: 678-686.

Kao JH, Chen DS. 2003. Clinical relevance of hepatitis B virus genotypes $\mathrm{Ba}$ and $\mathrm{Bj}$ in Taiwan. Gastroenterology 125: 1916-1917; author reply 1917-1918.

Kao JH, Chen PJ, Lai MY, Chen DS. 2000. Hepatitis B genotypes correlate with clinical outcomes in patients with chronic hepatitis B. Gastroenterology 118: 554-559.

Kramvis A, Kew MC. 2007. Epidemiology of hepatitis B virus in Africa, its genotypes and clinical associations of genotypes. Hepatol Res 37: S9-S19.

Lau GMP, Brunetto M. 2009. On treatment monitoring of HBsAg levels to predict response to peginterferon alfa-2a in patients with $\mathrm{HBeAg}$-positive chronic hepatitis B. J Hepatol 50: S333.

Lauret E, Gonzalez-Dieguez ML, Rodriguez M, Gonzalez M, Melon S, Rodrigo L, Rodriguez M. 2014. Long-term outcome in Caucasian patients with chronic hepatitis B virus infection after HBsAg seroclearance. Liver Int doi: 10.1111/liv.12461

Lavanchy D. 2004. Hepatitis B virus epidemiology, disease burden, treatment, and current and emerging prevention and control measures. J Viral Hepat 11: 97-107.

Liaw YF, Tai DI, Chu CM, Chen TJ. 1988. The development of cirrhosis in patients with chronic type B hepatitis: A prospective study. Hepatology 8: 493-496.

Liaw YF, Sheen IS, Chen TJ, Chu CM, Pao CC. 1991. Incidence, determinants and significance of delayed clearance of serum HBsAg in chronic hepatitis B virus infection: A prospective study. Hepatology 13: 627-631.

Liaw YF, Sung JJ, Chow WC, Farrell G, Lee CZ, Yuen H, Tanwandee T, Tao QM, Shue K, Keene ON, et al. 2004 Lamivudine for patients with chronic hepatitis $\mathrm{B}$ and advanced liver disease. $N$ Engl J Med 351: 1521-1531.

Liaw YF, Leung N, Guan R, Lau GK, Merican I, McCaughan G, Gane E, Kao JH, Omata M. 2005. Asian-Pacific consensus statement on the management of chronic hepatitis B: A 2005 update. Liver Int 25: 472-489.

Lim SG, Cheng Y, Guindon S, Seet BL, Lee LY, Hu P, Wasser S, Peter FJ, Tan T, Goode M, et al. 2007. Viral quasi-species evolution during Hepatitis B e antigen seroconversion. Gastroenterology 133: 951-958. 
HBV: Clinical and Epidemiological Characteristics

Lin CL, Kao JH. 2013. Risk stratification for hepatitis B virus related hepatocellular carcinoma. J Gastroenterol Hepatol 28: $10-17$.

Lin CL, Liao LY, Wang CS, Chen PJ, Lai MY, Chen DS, Kao JH. 2005. Basal core-promoter mutant of hepatitis B virus and progression of liver disease in hepatitis $\mathrm{B}$ e antigen-negative chronic hepatitis B. Liver Int 25: 564-570.

Liu J, Yang HI, Lee MH, Lu SN, Jen CL, Wang LY, You SL, Iloeje UH, Chen CJ, Group R-HS. 2010. Incidence and determinants of spontaneous hepatitis B surface antigen seroclearance: A community-based follow-up study. Gastroenterology 139: 474-482.

Livingston SE, Simonetti JP, McMahon BJ, Bulkow LR, Hurlburt KJ, Homan CE, Snowball MM, Cagle HH, Williams JL, Chulanov VP. 2007. Hepatitis B virus genotypes in Alaska Native people with hepatocellular carcinoma: Preponderance of genotype F. J Infect Dis 195: 5-11.

Lok AS, McMahon BJ. 2007. Chronic hepatitis B. Hepatology 45: 507-539.

Lok AS, Lai CL, Wu PC, Leung EK, Lam TS. 1987. Spontaneous hepatitis $\mathrm{B}$ e antigen to antibody seroconversion and reversion in Chinese patients with chronic hepatitis B virus infection. Gastroenterology 92: 1839-1843.

Lurman A. 1885. Eine icterus epidemic. Berl Klin Woschenschr 22: 20-23.

Mahoney FJ, Stewart K, Hu H, Coleman P, Alter MJ. 1997. Progress toward the elimination of hepatitis B virus transmission among health care workers in the United States. Arch Intern Med 157: 2601-2605.

Maini MK, Boni C, Lee CK, Larrubia JR, Reignat S, Ogg GS, King AS, Herberg J, Gilson R, Alisa A, et al. 2000. The role of virus-specific $\mathrm{CD} 8^{+}$cells in liver damage and viral control during persistent hepatitis B virus infection. $J$ Exp Med 191: 1269-1280.

Martinot-Peignoux M, Lapalus M, Asselah T, Marcellin P. 2013. The role of HBsAg quantification for monitoring natural history and treatment outcome. Liver Int 33: $125-132$.

Mast EE, Alter MJ, Margolis HS. 1999. Strategies to prevent and control hepatitis B and C virus infections: A global perspective. Vaccine 17: 1730-1733.

Maynard JE. 1990. Hepatitis B: Global importance and need for control. Vaccine 8: S18-S20; discussion S21-S13.

McMahon MA, Jilek BL, Brennan TP, Shen L, Zhou Y, WindRotolo M, Xing S, Bhat S, Hale B, Hegarty R, et al. 2007. The HBV drug entecavir-Effects on HIV-1 replication and resistance. N Engl J Med 356: 2614-2621.

Nguyen T, Thompson AJ, Bowden S, Croagh C, Bell S, Desmond PV, Levy M, Locarnini SA. 2010. Hepatitis B surface antigen levels during the natural history of chronic hepatitis B: A perspective on Asia. J Hepatol 52: 508-513.

Norman JE, Beebe GW, Hoofnagle JH, Seeff LB. 1993. Mortality follow-up of the 1942 epidemic of hepatitis B in the U.S. Army. Hepatology 18: 790-797.

Ocama P, Opio CK, Lee WM. 2005. Hepatitis B virus infection: Current status. Am J Med 118: 1413.

Ott JJ, Stevens GA, Groeger J, Wiersma ST. 2012. Global epidemiology of hepatitis B virus infection: New estimates of age-specific HBsAg seroprevalence and endemicity. Vaccine 30: 2212-2219.
Park BK, Park YN, Ahn SH, Lee KS, Chon CY, Moon YM, Park C, Han KH. 2007. Long-term outcome of chronic hepatitis B based on histological grade and stage. J Gastroenterol Hepatol 22: 383-388.

Raimondo G, Pollicino T, Cacciola I, Squadrito G. 2007. Occult hepatitis B virus infection. J Hepatol 46: 160-170.

Realdi G, Fattovich G, Hadziyannis S, Schalm SW, Almasio P, Sanchez-Tapias J, Christensen E, Giustina G, Noventa F. 1994. Survival and prognostic factors in 366 patients with compensated cirrhosis type B: A multicenter study. The Investigators of the European Concerted Action on Viral Hepatitis (EUROHEP). J Hepatol 21: 656-666.

Rijckborst V, Hansen BE, Cakaloglu Y, Ferenci P, Tabak F, Akdogan M, Simon K, Akarca US, Flisiak R, Verhey E, et al. 2010. Early on-treatment prediction of response to peginterferon alfa-2a for HBeAg-negative chronic hepatitis B using HBsAg and HBV DNA levels. Hepatology 52: $454-461$.

Schreiber GB, Busch MP, Kleinman SH, Korelitz JJ. 1996. The risk of transfusion-transmitted viral infections. The Retrovirus Epidemiology Donor Study. $N$ Engl J Med 334: $1685-1690$.

Sherlock S. 1987. The natural history of hepatitis B. Postgrad Med J 63: 7-11.

Stevens CE, Beasley RP, Tsui J, Lee WC. 1975. Vertical transmission of hepatitis B antigen in Taiwan. N Engl J Med 292: $771-774$.

Stevens CE, Toy PT, Tong MJ, Taylor PE, Vyas GN, Nair PV, Gudavalli M, Krugman S. 1985. Perinatal hepatitis B virus transmission in the United States. Prevention by passive-active immunization. JAMA 253: 1740-1745.

Sumi H, Yokosuka O, Seki N, Arai M, Imazeki F, Kurihara T, Kanda T, Fukai K, Kato M, Saisho H. 2003. Influence of hepatitis $\mathrm{B}$ virus genotypes on the progression of chronic type B liver disease. Hepatology 37: 19-26.

Thio CL, Locarnini S. 2007. Treatment of HIV/HBV coinfection: Clinical and virologic issues. AIDS Rev 9: 40-53.

Thio CL, Seaberg EC, Skolasky R Jr, Phair J, Visscher B, Munoz A, Thomas DL. 2002. HIV-1, hepatitis B virus, and risk of liver-related mortality in the Multicenter Cohort Study (MACS). Lancet 360: 1921-1926.

Tseng TC, Liu CJ, Yang HC, Su TH, Wang CC, Chen CL, Kuo SF, Liu CH, Chen PJ, Chen DS, et al. 2012. High levels of hepatitis B surface antigen increase risk of hepatocellular carcinoma in patients with low HBV load. Gastroenterology 142: 1140-1149; quiz e13-e14.

Tseng TC, Liu CJ, Yang HC, Su TH, Wang CC, Chen CL, Hsu CA, Kuo SF, Liu CH, Chen PJ, et al. 2013. Serum hepatitis $B$ surface antigen levels help predict disease progression in patients with low hepatitis B virus loads. Hepatology 57: 441-450.

Volz T, Lutgehetmann T, Wachtler P, Jacob A, Quaas A, Murray JM, Dandri M, Joerg Petersen J. 2007. Impaired intrahepatic hepatitis B virus productivity contributes to low viremia in most $\mathrm{HBeAg}$-negative patients. Gastroenterology 133: 843-852.

Wachs ME, Amend WJ, Ascher NL, Bretan PN, Emond J, Lake JR, Melzer JS, Roberts JP, Tomlanovich SJ, Vincenti F, et al. 1995. The risk of transmission of hepatitis B from $\mathrm{HBsAg}^{-}, \mathrm{HBcAb}^{+}, \mathrm{HBIgM}^{-}$organ donors. Transplantation 59: $230-234$. 


\section{G.S. Burns and A.J. Thompson}

Wasley A, Miller JT, Finelli L. 2007. Surveillance for acute viral hepatitis-United States, 2005. MMWR Surveill Summ 56: 1-24.

Webster GJ, Reignat S, Brown D, Ogg GS, Jones L, Seneviratne SL, Williams R, Dusheiko G, Bertoletti A. 2004 Longitudinal analysis of $\mathrm{CD}^{+} \mathrm{T}$ cells specific for structural and nonstructural hepatitis $\mathrm{B}$ virus proteins in patients with chronic hepatitis B: Implications for immunotherapy. J Virol 78: 5707-5719.

Yang HI, Lee MH, Liu J, Chen CJ. 2014. Risk calculators for hepatocellular carcinoma in patients affected with chronic hepatitis B in Asia. World J Gastroenterol 20: 62446251.

Yim HJ, Lok AS. 2006. Natural history of chronic hepatitis B virus infection: What we knew in 1981 and what we know in 2005. Hepatology 43: S173-S181.

Yu MW, Yeh SH, Chen PJ, Liaw YF, Lin CL, Liu CJ, Shih WL, Kao JH, Chen DS, Chen CJ. 2005. Hepatitis B virus ge- notype and DNA level and hepatocellular carcinoma: A prospective study in men. J Natl Cancer Inst 97: 265-272.

Yuen MF, Yuan HJ, Wong DK, Yuen JC, Wong WM, Chan AO, Wong BC, Lai KC, Lai CL. 2005. Prognostic determinants for chronic hepatitis B in Asians: Therapeutic implications. Gut 54: 1610-1614.

Yuen MF, Wong DK, Fung J, Ip P, But D, Hung I, Lau K, Yuen JC, Lai CL. 2008. HBsAg Seroclearance in chronic hepatitis B in Asian patients: Replicative level and risk of hepatocellular carcinoma. Gastroenterology 135: 11921199.

Zakaria S, Fouad R, Shaker O, Zaki S, Hashem A, El-Kamary SS, Esmat G. 2007. Changing patterns of acute viral hepatitis at a major urban referral center in Egypt. Clin Infect Dis 44: e30-e36.

* Zoulim F, Durantel D. 2014. Antiviral therapies and prospects for a cure of chronic hepatitis B. Cold Spring Harb Perspect Med doi: 10.1101/cshperspect.a021501. 


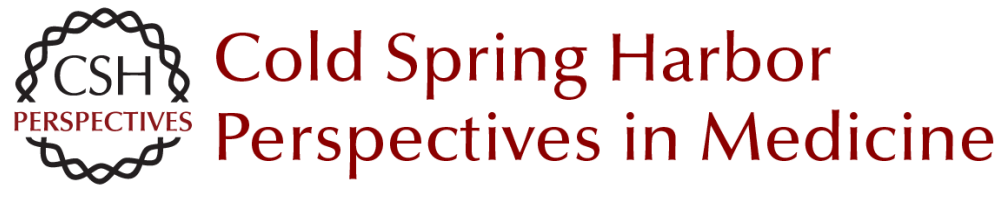

\section{Viral Hepatitis B: Clinical and Epidemiological Characteristics}

Gregory S. Burns and Alexander J. Thompson

Cold Spring Harb Perspect Med 2014; doi: 10.1101/cshperspect.a024935 originally published online October 30, 2014

Subject Collection The Hepatitis B and Delta Viruses

Hepatitis B Virus X and Regulation of Viral Gene Expression

Betty L. Slagle and Michael J. Bouchard

The Woodchuck, a Nonprimate Model for Immunopathogenesis and Therapeutic Immunomodulation in Chronic Hepatitis B Virus Infection

Michael Roggendorf, Anna D. Kosinska, Jia Liu, et al.

Mouse Models of Hepatitis B Virus Pathogenesis Matteo lannacone and Luca G. Guidotti

Therapy of Delta Hepatitis Cihan Yurdaydin and Ramazan Idilman

Immune Response in Hepatitis B Virus Infection Anthony Tan, Sarene Koh and Antonio Bertoletti

Hepatitis D Virus: Introduction and Epidemiology Mario Rizzetto

Management of Chronic Hepatitis B in Patients from Special Populations

Ching-Lung Lai and Man-Fung Yuen

Hepatitis B Virus Genotypes and Variants Chih-Lin Lin and Jia-Horng Kao
Origins and Evolution of Hepatitis B Virus and Hepatitis D Virus

Margaret Littlejohn, Stephen Locarnini and Lilly Yuen

Assembly and Release of Hepatitis B Virus Lisa Selzer and Adam Zlotnick

Hepatitis D Virus Replication John M. Taylor

Treatment of Liver Cancer Chun-Yu Liu, Kuen-Feng Chen and Pei-Jer Chen

Hepatitis B Virus and Hepatitis D Virus Entry, Species Specificity, and Tissue Tropism Koichi Watashi and Takaji Wakita

Hepadnavirus Genome Replication and

Persistence Jianming Hu and Christoph Seeger

The Chimpanzee Model for Hepatitis B Virus Infection

Stefan F. Wieland

Hepatitis B Virus Epidemiology

Jennifer H. MacLachlan and Benjamin C. Cowie

For additional articles in this collection, see http://perspectivesinmedicine.cshlp.org/cgi/collection/ 